\title{
THE AIM AND OBJECT OF AN ACTIVITY PROGRAM
}

\author{
Dr. Edgar G. Johnston
}

Professor of Sccondary Education and Principal of University High Shcool, University of Michigan, Ann Arbor, Michigan

Mr. Chairman, fellow-members of the Department of Secondary-School Principals, and distinguished guests. In the event that any of you in the back of the room cannot hear me I shall appreciate it if you will raise your hands, and I shall raise my voice.

The extra-curriculum activity movement as an organized consideration of the program in the school has reached its majority; it has come of age, for it is just about twenty-one years ago that the Chairman of the panel which you are to hear later this afternoon, and the acknowledged dean of the extra-curriculum movement in America, Dr. Fretwell, organized the first course in extra-curriculum activity.

If, in the discussion that follows, I seem to dwell especially on faults or shortcomings, it is not without recognition of the distinct values which the extra-curriculum program has brought to our schools. May I rather hope to play the role of a friend of the family who is interested in the growth of this young Mr. Extra-Curriculum Activity, but who is openminded to see those factors which may hinder his most effective development.

In the attitude of teachers, administrators, the public, to extra-curriculum activities-well perhaps mainly just of teachers and administrators, for I think the public has in general been more alert than we to possibilities-in the attitude of teachers and administrators, I think we can discern three observable attitudes. The first was one of opposition, that extracurriculum activities was something that interfered with the real business of the school-learning lessons. That attitude was represented by a comment I heard in the course of an address by a distinguished scholar and gentleman of the old school, who had occasion to refer to what we speak of as extra-curriculum activity. His comment was, "Extra-curriculum activities. A new-fangled term for what in my day was known as dissipation." I think fortunately the point of view he represents would be found by very few in our schools to-day. However, if activities have become respectable they have still been tolerated rather than encouraged by some teachers, some schools, some administrators.

That attitude I think can be found on the part of those who rigidly insist that pupils must pass in their regular school work if they are to be permitted any experience in the extra-curriculum program. To them extracurriculum activities are a sort of scholastic ice-cream that is to be given only to those who have eaten their carrots and spinach, even though some of them may be allergic to spinach.

You are all familiar with Dr. Fretwell's famous two theses, I shall not repeat them to you, but certainly the hope of the extra-curriculum pro- 
gram has been that it would develop citizens of a democracy, who would be better able to perform their duties, personalities richer in creative activity, individuals who are more sensitive to social values and who have more developed ability.

I believe that failure to achieve what we might reasonably expect the extra-curriculum program to do in our schools may he assigned to certain administrative weaknesses, and that to us particularly who are the administrators of schools there are some very definite considerations we need to give our most earnest attention. I shall point out some of these weaknesses as they seem to me, in the administration of the program.

The first of these is that many schools have adopted the forms of an activity program without any real understanding by teachers and pupils of the function it should perform. We have had hastily introduced examples of student councils which very frequently have been as hastily removed when without consideration of what they were to do they failed to achieve any real educational purpose.

We have had top-heavy club programs, started in schools which then have fallen by their own weight.

We have had home rooms which were home rooms in name only and were mainly an administrative routine.

Too frequently we have had the copying, in rather slavish imitation of something that was being done some place else, and has seemed to be effective there, without asking what the purpose was it was expected to serve, and consequently how it could be made to perform that function.

Several years ago I had occasion to participate in a state survey in another state. We visited forty-two high schools in that state. In all of them we found home rooms, but we found only one activity common to the home rooms and that was taking attendance. Actually at one of these schools they herded the pupils together in what they called home rooms, for five minutes in the morning, for a roll call; at twelve o'clock they brought them back for three minutes to see that they hadn't escaped; at one o'clock they came to the home rooms again, and again were checked in for five minutes, and again at four o'clock there was another threeminute round-up to be sure that all survivors might be checked up and sent home for the night. Certainly that was no home room in any real sense.

The second point I should like to make is that we have really been afraid of democracy; we have lacked faith in the ability of pupils to plan intelligently, to work coöperatively, to make decisions and to accept responsibilities, and that in my judgment is the most crucial problem and the most critical failure of activities programs as they have been carried out in our schools of to-day. 
We are living in an age when democracy is on the retreat throughout the world, when whole nations are regimented into servile obedience to a self-appointed leader. We need to develop the ability to choose leaders wisely, and one chooses leaders wisely only by having experience in choosing them and by having the opportunity to make mistakes and to learn by those mistakes.

We have been so afraid that pupils would make mistakes in judgment that we have not allowed them to make judgments, so afraid that they would choose the wrong leaders to represent themselves that we have picked their leaders for them, and I have observed this year, I have had an opportunity of visiting a good many schools throughout the country, I have seen some excellent things in the activities program, but repeatedly it has seemed to me the thing that stood out was the failure to realize how much responsibility pupils really are able to take, and the examples which have shown that recognition and that confidence may have been the high lights in the activity program in the American school.

I was interested in the question which was presented by a newly elected student council president to his principal. His question was: "Well now as student council president just how much authority have I?"

The answer of the principal, and I think a sound one, was, "Just as much as you want, and are willing to take responsibility for."

It seems to me we need to recognize that it is not a case of student or faculty domination of a school, but of student and faculty participation in administering this very complex, dynamic organization which is the modern secondary school, and that means a willingness on our part to give just as much responsibility as pupils are ready to take, and that means, more often than we are ready to recognize in them.

The third point I should like to make is that participation in the extracurriculum program has been limited to too few pupils. Sometimes by this scholastic limitation I mentioned earlier, by insisting that the pupil who has not passed in algebra, or in English or in Latin may not be a member of a club or run for an office or participate otherwise in the school.

To my mind if we really believe the values we have claimed for the extra-curriculum program, if we really think that this is preparation for citizenship, in learning to do by doing, it would be just as illogical for us to say to John Smith, "You may not take English, you failed in algebra last semester." If we think of these as complementary parts of a total educational program of the school we need to think of them in terms of what may be most significant for each individual pupil, and for many pupils in many schools to-day I believe the most significant educational experience they are receiving is that found in what we call the extra-curriculum activities of the school. 
And then we have failed to provide for distribution of experience, we have allowed too frequently a small number of the more capable to assume the greater part of the extra-curriculum opportunity the school provides. Let me illustrate: in a school I visited once there was an excellent use of the public address system. A student news broadcast was given, it was a semi-weekly event, I believe. The student who presented this in very wellchosen words, gave the news first of the school, then of the local community, then national news, and then international news, with appropriate comment. It would have done credit to many of the commentators of our national networks.

The next day there was an assembly. The assembly contained among other phases it had a presentation of a newly designed school seal, very effectively done, in a brief and fitting series of remarks, by a student, with acceptance of the seal on the part of the student body; the student who made the acceptance speech was the same one who had done the broadcasting the day before.

Then there followed a play, an excellent play, well presented, one which demanded a good deal in the way of dramatic ability, particularly by the leading male part, and that leading part was played by the same boy who had made the student broadcast the day before, and had accepted the seal a few minutes before the play.

A few years ago I had occasion to analyze the participation of pupils in activities as represented after their names in the senior annual. In one school which had a very extensive activity program of which it was proud, one pupil had been, as indicated in this list of honors following his name, the president of the student council; the president of the senior class; the colonel R. O. T. C.; captain of the football team, lead in the senior play, et cetera, et cetera. Actually there were for the four years he had been in the school, forty-two designations after his name, of something of enough importance that he wanted to have it included in his history.

However, in that same school, in that same senior class there were nineteen per cent of the student body of the seniors for whom nothing was presented, they had had no experience of the extra-curriculum type of sufficient importance to put it after their names.

Too frequently a school doesn't even know how widely this extracurriculum experience is being distributed in the school.

The next point I would like to emphasize is that the competitive aspects of the program have been over-emphasized. The winning of contests has long been a major consideration in athletics, and we have had sometimes the contrast, the division of the student body into gladiators and bench-warmers. 
There is certainly a very definite degree in which this over-emphasis on winning of contests vitiates the very purpose that the athletic program is intended to carry out, and has results which are undesirable both for the spot-lighted participant-small number of participants-and for those who may obtain a distorted sense of values through over-emphasis on winning as being the thing that counts on the part of the student body.

I have been very glad to see the efforts which have been made especially by some of our state principals association groups to make an intelligent study of contests in the various fields, not only in athletics but in the field of music, in the various other fields into which this competitive idea has developed, make a study of those and to attempt to restrict those in such a way as to get the legitimate values which competition may present.

Certainly in addition to the limitation which comes in limiting the activity in speech, in dramatics, in music activities to those who are competent to appear and to win for a school, it may deprive those who most need the kind of experience that that activity presents, and may also even conflict with the purpose of the activity itself. Beating somebody else has nothing to do with the appreciation of a symphony or with an understanding of socialized medicine, and the sooner we recognize that fact and focus our attention on the real functions to be performed by the activities, the sooner will we provide the distribution of activities which is to be desired. Particularly, as Bertrand Russell brought out so clearly in his address of Saturday evening, it is critically important for us in democracy to develop the ability to coöperate, to focus our attention on those points we have in common and not upon those points in which we are attempting to be superior to someone else.

Then the activity program has too frequently been extra-unrelated to the curriculum program of the school. A recognition of the common aims and relationships which both of these phases of the program have as part of the total educational program of the school, will result in improved contribution from each.

I believe it was L. P. Jacks, the English writer on educational topics and a former headmaster of a well-known English school, who said appropos of education and recreation, "To the wise individual there is no dividing line between his education and his recreation, his work and his leisure, his vocation and his avocation; many times if you ask him whether he is working or playing he could not tell you which. To himself he seems to be doing both; enough if he does it well." Something of that spirit has carried over into the curriculum where there has been developed a vital relationship between the extra-curriculum activities and the curricular activities, and where the two have been viewed as common parts of a larger educational program to which both have a contribution to make. 
And then, there has been no consistent effort to evaluate activity in terms of the fundamental objective we have set up for them. We have been content too often in a rather aimless way to continue activities hecause we had them. Well, we have always had a Latin Club, for instance, we have always had an assembly program; we have always done this or that, and without measuring what the real returns are in terms of the things that we say the activity program should present to the school.

I remember on the old farm where I grew up, that we had a raspberry patch which was tended rather carefully for some years. One of the chief jobs was cutting out the canes. Each fall you would cut out the old, dead canes, and that made room for the new shoots to come up, and if you failed to do that, as eventually when this was allowed to lapse, we did, it developed from a well-cultivated and well-tended patch into a bramble patch in which it was almost impossible to get in, and to get the fruits that were there. I think sometimes our activity programs have been pretty much like that, where dead wood has been allowed to continue without any real consideration as to whether it was performing functions or what the values that might be performed were.

Certainly the improved personnel records and functional consideration of the curriculum in terms of the experiences that pupils have under the auspices of the school has done much to focus our attention upon the objectives. I believe that one of the major developments to be achicved in extra-curriculum activities is that of devising and utilizing effective means of measuring improvement.

If I may mention, then, two more major weaknesses, it seems to me the teacher training institutions have failed to provide appropriate experiences for prospective teachers to prepare them for responsibilities in this field.

We have seen that there was adequate preparation in mathematics, we have outlined what the major should be in Latin or in English; we have seen to it that there was practical teaching provided in each of these lines.

Fortunately, as a beginning of this development we have seen extracurriculum courses coming in, particularly in our summer school sessions. Usually they have been a matter of teachers who have been out teaching coming back to find out something about the activity into which they have been thrown as they went into the schools. But if we believe that we learn to do by doing, what our whole extra-curriculum philosophy has told us, it certainly applies to teachers who are being prepared for participation in teaching. You do not learn to swim until you get into the water, and the extra-curriculum experience of the teacher does need some opportunity for controlled supervised effective participation. 
At a recent meeting of a state principals' association in the committee report on teacher training, I thought the most significant point that was made by the chairman for that committee was that our teachers come to us well trained in their subject fields, but they do not know how to run a home room, they know nothing about sponsoring a club, they are not prepared to take over the responsibility for the various activities, and we have to train them for that after we get them in the schools. I believe that all the way through this training has to be a coopperative thing, and some type of interneship in the whole of the program is the method that will provide for the most effective preparation.

And then, finally, duties in relation to activity program have not received adequate recognition in considering the teacher's load, either by administrators or by the community.

I am not suggesting that for every club sponsorship a class should be withdrawn from the teacher's load; I am suggesting that we do the same thing for the teacher that we do for the pupil in an intelligence guiding program, that we think of his total contribution to the school and that we come to get the public to recognize what this total program of the school is, and to set up what is a reasonable standard for that in terms of its effectiveness.

Well, now to get back to this young adult, Mr. Extra-Curriculum, who has just reached his majority. I may seem to have been very critical here and not to have had a very optimistic view; I think that would be a mistake. I do not want to give the impression that I think that his weaknesses are constitutional, that he has developed hardening of the arteries, that there is no hope. I do think that there is need for intelligent attention to a reasoned regimen, to an intelligent diet, and particularly that we need to focus attention on those schools, on those types of organizations and there are many of them, that are doing in some phase of this program an effective and a stimulating, and an active job, and particularly we want constantly to be asking the question: what is this activity for? And: Are we achieving that? Are we developing self-reliance, the ability to make decisions as independent members of a democracy, living in a democracy to develop creative ability on the part of youth?

The best answers to this are to be given by the youth themselves who are after all the ones who provide the real dynamics of the activity program, and who are the real evaluators of that program.

So I think it is fortunate for the program here this afternoon that it does include as its major phase, the discussion of activities by pupils themselves.

We have long known of the Cleveland high schools as representing outstanding development in the publications, in the student participation 
in school control, and in other phases of the activity program. Those of us who heard their musical organization Saturday night were certainly thrilled by the performance they presented there. I have a feeling you are going to be equally thrilled in hearing them discuss this topic to which I have provided just the curtain raiser. [Applause]

\section{DISCUSSION}

Chairman Wellwood: We have just listened to an appraisal by an appraiser; we are now to listen to an appraisal by a group of participants.

It is not my job to present these young people to you, but to present the leader. Personally I am hoping to get just a little bit of personal satisfaction out of it. Sixteen or seventeen years ago I enrolled in a course in Extra-Curriculum Activities in Teachers College in Columbia. The second day the class met, the teacher in charge of the class called upon me to stand up and introduce all the people who sat in the same row with me, and tell where they had come from. My face was considerably red. I am hoping to-day that Dr. Fretwell will have to take his paper out and look at it when he is introducing this group of young people to you. [Laughter]

Dr. Elbert K. Fretwell (Professor of Education, Teachers College, Columbia University, New York City):

Ladies and gentlemen, since we believe in the plan of participation of these pupils, I shall get around Mr. Wellwood. Instead of doing the work for my classes, I insist that they do their own work; therefore each individual is going to introduce himself or herself. [Laughter and applause]

We had not planned on such a large audience, although we had expected one almost as goodlooking; as a result we had not paid any attention to this public address system, for which we have just three outlets. Just how we shail manage these we do not know. This affair is not entirely new to this dozen young people that we have here, but before we go any further I will ask each of you to introduce yourselves, give your name, and the school from which you come.

Edgar Becker, representing the Student Council of John Marshall Senior High School.

Mildred Guilfoyle, representing the Student Council of John Hay High School.

Joe Boydos, representing John Adams High School.

Roy Unger, from Cleveland Heights High School.

Russol Myers, representing Patrick Henry Junior High School.

Evelyn Lawry, Garfield Heights High School, Junior and Senior.

Richard Little, of Empire Junior High School.

Ray Dottore, Audobon Junior High School.

Lois Hainley, West High School, Junior and Senior. 
Tim Gunn, Lakewood High School.

Nina Panariisi, representing Collinwood High School, both Junior and Senior High School.

Ray Willson, of East Technical High School.

Dr. Fretwell: For fifteen years here in Cleveland they have had the Student Leaders' Conference. This Conference has been carried on by the lady to whom we are greatly indebted for bringing to us this afternoon, some members of this Conference-Miss Ethel Parmenter of East Technical High School-stand up and take your bow, Miss Parmenter-she has done all the work. [Applause]

Now we will do our best with the limited facilities of the public address system. Naturally, we cannot talk back and forth quite as much as we would if we could panelize with a relatively small group.

To give you the back-stage side of this: I had the privilege of meeting with most of these young people yesterday afternoon. We did not at any time rehearse anything we are going to say. I do not know what they are going to say. You don't know what they are going to say. But this we know, we emphasized the fact that we'd tell the truth as we saw it, fearing God but little, and man not at all, and that we would be courteous about it, but saying the kind of things they have to say.

May I, in their behalf, say one other thing?

Dr. Johnston of course could generalize from a wide experience. You know, you really have to become a college professor of education, to generalize widely from a minimum of material. [Laughter] We will begin with home rooms, then progress to student councils, clubs, et cetera, et cetera, in that fashion adjourning by four o'clock. We hope, if we can, at the end of the time to give opportunity for questions from the floor which the pupils will have the privilege, if they care to, of answering, and saying what they think about.

We are not going to have set speeches at all. I am going to ask questions and we will take them up here and there, and get at the matter of the answering of those particular questions. You came here of your own accord. [Laughter] You recognize the conditions under which we work; the size of the hall, and all who have conducted or been members of panel discussions have a lively appreciation of this particular problem. We would like to work without the public address system; we know that we cannot make you hear, therefore with only three of these little microphones we are going to go at it in this particular fashion.

Now we shall present a good deal of concrete material, undoubtedly, but (how do we do it in this school, how do we do it in that,) to the end that we may generalize a bit and say what we think of it in the end. 
I learned to call cattle in a neighboring state, and I can usually make them hear if they are long-horned enough. [Laughter]

We shall begin with home room.

I shall talk without the "mike," so that they may have them freer to use; if I seem to holler don't think I am just doing it to enjoy myself-I am, but don't think that. [Laughter]

We have twelve schools here, not just East Technical High School, but twelve of them.

Which ones of you come from Junior High Schools?

... three raised their hands. ...

All boys as it happens in that case.

How many of you come from six-year schools?

... four raised their hands. . . .

How many come from three-year schools?

... four raised their hands. . . .

How many of you come from schools that have home rooms?

... all raised their hands. ...

One hundred per cent. Isn't it lucky we are meeting in Cleveland and in this general neighborhood?

I am going to begin with Ray Dottore; he is from a Junior High School. Tell us, Raymond, a little about the Junior High Schools-what time of day you have your meeting, how long you have it; what goes on in a home-room period-take two or three minutes if you want to.

RAYmond DotToRe: Our home room meeting starts at nine-forty-five and ends at ten-fifteen. Between that time we have a broadcast from our principal, and he tells us of lost books and all such things. [Laughter and applause ]

We are organized upon a homogeneous basis; we have a strong competitive spirit; we have attendance, and inter-room games, and ticket sales, contributing to community fund, and subscribing to our school paper.

Dr. FRETwell: Well, let's take the other Junior High Schools-this fellow was sick yesterday, he is just out to-day for the first time. Tell us a little about yours.

Richard Litrle: Our home room starts at eight-ten and lasts until ten minutes to nine in the morning, and during this time on Monday the bulletin and any other special notices are read, announcing club meetings and student council meetings. During home-room periods the rest of the week, home-room programs are held, and there is a special bulletin tha comes out at the beginning of the term, which tells the different home rooms what programs they are supposed to have. 
In the bulletin there are also other notices for dances. We also sell tickets for dances, and that is about all.

Russol Myers: Our home-room program starts at nine-thirty usually lasting fifteen minutes exceping on Friday, we then have a half-hour period. Every day of the week except Friday we just read bulletins put out by the office and take the attendance; on Friday we have our choice of anything that we might like to do.

Most home rooms in my school-Patrick Henry-have home-room organizations, that is, they have a president, a vice president, a secretary, and a treasurer. The president usually appoints a committec to take care of entertainment on Friday. What they usually do is to get talent from the school; a boy might play a harmonica, a saxophone, and they are pretty well in use every Friday because the various rooms bid for them.

There are no orders sent out by the office as to how the time must be used in the home room, but the usual procedure is as I have outlined every day in the week.

DR. FRETwELL: Suppose we hear a little about home rooms in senior high schools.

Nind Panarisis: In this period the chief function is guidance. This guidance consists of social, moral, educational, and vocational, and each guidance is carried out when the occasion arises.

Our home-room organization consists of a student councilor, a student council alternate, a business manager, and a secretary. They all have their various duties, some of which are councilor-our student councilor is president of the home room; he attends the student council meetings and takes charge of the class in the absence of the home-room teacher. The student council alternate takes over the various duties of the councilor if he happens to be absent.

The business manager is in charge of all tickets. Since we have a rather good athletic program at our school, we have many athletic contest ticket sales, and we have a special person to take care of these tickets.

Then our secretary has charge of attendance, and various other duties throughout the home room, which the other officers do not take care of.

We have special programs that we have during the home-room period; we have a social room at our school and sometimes we go there to spend a home-room period. Our home-room period is passed in various ways but it is routine usually.

Dr. FRETWELL: Now I think it would meet with your approval if these people would tell us-and they have no idea I am going to propose the next question--whether they think these schools that they come from, ought to have home-room periods or not. 
The question probably is biased because of the fact that they are in home-room periods of one kind or another and they can say in connection with that (if they care to) how they think they could be improved.

Let me ask a few of them whether they think we ought to havebecause 1 am going to challenge everything we have this afternoonwhether they think we ought to have home-room periods or not.

Edgar Becker: I think we should have home rooms, definitely. I think the student participation in home rooms should be greater than is allowed in some schools. I feel in some schools the teacher regulations are too strict. Such students as the president, the vice president, and other officers of the home room should be given a freer hand, and the teacher should act as a guide rather than a pedagogue on a pedestal who looks down to see that you do the right thing during that period. [Applause]

I find students will be more free in their opinions of how they think a school should be run. They won't want to take a teacher's job, of course, but they like to give their opinions as to how the program should be arranged so they can have time for extra-curriculum activities, and how they would like their study halls arranged in such manner that they could participate in those activities.

Mildred Guilfoyle: I particularly like the home-room organization, especially the way we have it in our school.

We have our home rooms organized on a permanent basis; we enter in 10-B and remain until 12-A and in this way we have a chance to become acquainted with the home-room teacher, and there is a real guidance by the teacher and our home-room advisors. I feel that particularly in John Hay our home-room organization is set up quite well and I do approve of it.

JoE Boydos: I also voice the same opinion as Edgar, that the teachers sometimes are a bit too strict. Naturally I see some smiles in the crowd. Sometimes the teacher does this unwillfully, perhaps he means well sometimes [laughter] however, I suppose we are the younger blood and we like something fast and furious.

The home rooms at our school are split up on the general basis of. male and female, and we get together in the home rooms and we generally talk over the problems of the world in our home rooms, and we have a chance to know everybody, and in this way we increase attendance, by the fact that sometimes we go out and challenge a girls' home room to an attendance contest - that is for the month-the loser foots the bill for a party.

On the other hand, as Edgar said, home rooms aren't run by the presidents and vice presidents and officers in the home room, and they really should be given a freer hand. 
Dr. Fretwell: We will take one more.

RoY UNGER: I believe they are an absolute necessity. We are handicapped by a too short home-room period. We have public address announcements too and even some of the teachers complain at not having enough time. As one teacher put it, when we have a long home room the good ones get better and the poor ones get worse.

I believe Miss Parmenter had the answer to that question when she said that if home-room teachers were trained to take home rooms and paid for it as a separate class, home rooms could really be improved.

I feel that if they were on that basis a great deal could be gotten out of them. I feel even though we have short home-room periods at our school and cannot do a great deal, we get a good deal out of them.

... (a request from the floor was made to ask questions). . .

Dr. Fretwell: In the matter of questions, if you are willing to let me drive straight through and then we can take all comers-one for instance wants to know what kind of sponsors these people like. Well, I am not turning that question loose just yet.

If you are willing in that fashion, let me be arbitrary in this because you know after you take the bit in your teeth I don't know whether I will ever get it back or not. But we want the questions from the floor later.

I understand that all of us come from schools that have student councils. I want particularly to hear about how they are organized, first briefly, and then what do the student councils do.

Russol, I am going to ask you to talk about this: how is your student council organized; is your home-room representative chosen by the principal as one so-called student council I know of is, or how is that done?

Russol MYers: Our representatives are chosen by the home-room group, that is one of the functions of the home-room group organizations, they choose representatives for the student council and the safety council.

The representatives of the student council are sixty-two in number. We have provision in our Constitution which allows councilors-at-large to become members of the student council, so with that we have about seventy in all, in our student council.

The representatives of the different home rooms give their name and home-room numbers as they arise; in that way we can take attendance. Our student council accomplishes many things, one of them we are very proud of was accomplished Tuesday of last week. We had a portrait of Patrick Henry presented to our school. We have been working for that for the past four years and we are very proud to have finally obtained it.

Some terms the representatives in the student council choose the presi- 
dent, the vice president, and other members of the executive committee by themselves, and some terms we let the entire school participate in the election. But what we usually do, so far as electing nominees for the different offices is concerned, is to let the representatives of the council do that and then put the vote to the school as to who will be president.

I think one thing very few schools have tried, and which our school has tried and found very interesting is the fact that we send representatives of our student council to the elementary schools and we find that we get a large response from this and it is very satisfactory. What we do is to get six A's interested in the work we do at Patrick Henry, and some 7B's and 7-A's and 8-B's, and interested in the student council and help our school along, and that is what we want, people who will work and help our school.

Dr. Fretwell: Mr. Becker-the same question.

Edgar Becker: Our council representatives are elected in the home room; we have a representative and an alternate. The student council consists of a president, a vice president, a secretary and a treasurer, and they are elected at the end of every semester. There are certain qualifications which they must measure up to: an average of 85 for the entire year's high-school work is required in order that a person may become a candidate. Election booths are set up at the end of each semester, where a person must register before he may vote. At this vote it requires a majority to elect a candidate to office. In the student council there are various committees, Welfare Committee, Civic Improvement Committee, Standards Committee, Social Committee. The Social Committee regulates or takes carc of all school dances. In the council there are various projects which we attempt every semester. Some, in the past, have sponsored the Honor Society, organizing student government, study halls, a student government lunch room-the latter is our newest practical project which was accomplished this semester. In this student-governed lunch room the students select tables at the beginning of the semester, each chooses a host or a hostess and they remain the entire semester and we find luncheon has improved greatly.

All business which goes from the student council must of course be passed by the principal of the high school, and as yet we have not found any way of overriding the principal's veto. [Laughter]

Other requirements for officers are the president of the student council shall be a member of the senior 12-B or 12-A class; the treasurer shall be a member of the 11th or 12th grade, and the sccretary shall have had typing and shorthand, so that she can take care of the minutes at every meeting. They are distributed to the home room where they are read the last five minutes of the home-room period on Tuesday. 
Tim Guns: At Lakewood we pride ourselves on what we call one of the most democratic student council bodies in the city of Cleveland. Our student council body is based on the home-room plan, that is, each home room has one representative. These representatives meet together and four weeks before our final exam week they nominate people for the various offices, a president, a secretary, and a treasurer. We have no restrictions upon these nominations. Of course the students that are nominated must be members of the student council. On the following weik we also open the nominations up again, and if there are any further nominations we accept them, and close the nominations that week. On the following week the students are given a chance to draw up their partics and present their platforms.

At Lakewood we are very liberal in our campaign. I don't know if any of you who come from Cleveland saw any of the several articles in the Cleveland newspapers about the way our campaign is run at Lakewood. I have here one of our posters which probably if it had been suggested it be put up in some high schools they would have thrown the student out. I am going to show you one to give you an idea about our campaign at Lakewood.

... unrolled printed poster which read as follows....

\section{FOR STUDENT COUNCIL ELECT \\ TIM GUNN, President \\ JEAN BISHOP, Secretary \\ CHAUK PRESSLER, Treasurer \\ PIROGRESSIVE LIBERAL. PARTY}

Dr. Fretwell: You will understand, this is Tim Gunn holding the sign up. [Laughter]

Tim Gunn: I am proud to say that the Progressive Liberal Party was victorious; the other party was the Student Progressive Party.

You are probably wondering why we divide up into parties. We figure that if the students get together in parties they can draw up a better platform, because they are going to work together. Also we allot a certain amount for expenditures, each student is only allowed to spend fifty cents. Accordingly, if you get into a party you have that much more to spend for advertising. You are probably wondering about a sign like this-it costs quite a bit to have one made. We are always ready to accept donations, and that was a donation.

You may also be interested to know that we are given a chance to have our brass bands and our speakers in the halls and things like that.

During the campaign this year we had several speakers hooked up throughout the halls. During these programs we give a chance to some of 
the outstanding students of the school to speak for the various parties.

Now that we have taken care of the election, we have our president elected; each home room is allowed as many votes as there are people in the home room. If a student is absent he loses his chance to vote. There are ballots passed around in the home rooms, each student votes for one for president, for one for secretary, and for one for treasurer. The student receiving the highest number of votes of course is the president; the student receiving the highest number of votes for secretary is recording secretary, and the girl receiving the second highest number of votes for secretary is the corresponding secretary; the student receiving the highest number of votes for treasurer is treasurer.

The student council at Lakewood, I believe, has done a great deal. The idea about the election is of such a democratic nature, it was brought about by a student council president about six years ago.

We are very proud of our Principal at Lakewood. He lets us do a very great deal. He has a lot of faith in the students and we are certainly proud of him.

Last semester one of the things that came up in the campaign was about car parades at Lakewood. We realized that many of the school students would like to see some of the out-of-town games. The student council got the idea of holding car parades. The faculty backing was not so strong for our first one, but we received permission to go ahead. The day of the game came. The game was in Elyria, forty miles from Lakewood, quite a distance to expect students to go. They practically floored me. We had about seven hundred students go to Elyria to the game. That was the largest attendance at an out-of-town game in the history of Lakewood, and we have had some good teams there.

Another thing we have done at the student council at Lakewood is to install honor study halls. That was something that came up in the campaign this semester. In these study halls there is no attendance taken, no regular seats are assigned. Students are put in on the basis of whether they are a member of the honor society or on the honor or merit roll the past semester, a member of the student council for the eleventh or twelfth grade, or recommended by the home-room teacher.

I could go on here for hours and hours talking about what our student council has done, but I am sure you would like to hear from some of the other student councils so I will give up. [Applause]

Dr. Fretwell: To be honest, I believe Tim likes his student council idea.

We will take one more on that.

Nina Panarisi: While we are on the idea of student council, I would like to say that my school conducts its elections in a different way. We 
have our elections in the student council only and not the entire school participating in it.

I would like to say that our student council, like Tim's is composed of representatives from home rooms, that is, one representative from each home room. In the student council we have members representing various systems throughout our school. We have commander of the hall guards, commander of the cafeteria guard, and commander of the news movie guards. Just recently we have a social room established in our school and we have a commander for that.

We also have chairmen of the various other committees like our student control, study halls, lost and found, ticket committee, library guards, safety committee, athletic committee, and assembly committee. These various chairmen all have their duties. Each week, if they have anything to report on or if they have any special news that they want to get across to the students throughout the school they say it in the council meeting and the representative tells the students on the next Monday.

We have both a senior and a junior student council at our school but we have different meetings for each. The junior student council holds its meeting on Tuesday, the Senior on Friday.

Although these meetings are held separately, our executive meetings are held together. There is a faculty advisor for each student council, that is, both senior and junior.

In previous years we had all the committee heads I named on our executive committee, but starting last year we thought that it would be better to reduce our number of executives and in that way get more compact ideas. You know if you get too many hands in the soup, as the old saying goes, you don't get much good out of it, [laughter] so we thought if we had less people we would get better ideas and we would get more accomplished.

Dr. Fretwell: Well, that is a grown-up idea.

Nina Panariss: We sponsor various projects in our school, one of the main ones is assemblies. It is rather hard, getting a good assembly program. The students want something up-to-date; they like speakers but they do not seem to care very much for them if you get too many of them, so we have quite a problem in our school in getting assemblies that the students really enjoy; each semester we ask the students to hand in suggestions so that the assembly chairman may get some ideas of what the students really want. She succeeds pretty well. This semester I am in charge of that job and I can realize what a chairman has to go through to get an assembly program that the students really enjoy.

The noon movie guards are in charge of noon movies. At our school we have noon movies during lunch period. I would like to admit that they 
do a very good job of it. Our faculty sponsor really deserves credit, and the boys deserve credit for the fine work they do.

Russol Myrrs: I would like to ask a question: do you have activities tickets for your noon movies and other activities, or do you pay for the noon movies, two cents or a nickel or whatever your charge is as you go along?

Nina Panariss: We do not have activities tickets at Collinwood; but we are now trying to get them.

DR. FrETwell: We will take up this whole matter of activities tickets before we get through.

I have heard, Miss Guilfoyle, that at John Hay you have a real citizenship campaign; I heard about it from your Principal, Mr. Moore, years ago. I would like to check up on this W. L. Moore, who is an old student of mine, and I would like to hear about this citizenship stuff over there.

MildRed GuILfoyle: Our citizenship program in John Hay has grown up from our own needs and conditions. It isn't anything we have followed along the line of anything any other schools have done in training their students to be good citizens.

As soon as the students enter John Hay as 10-B's one of the first things we like them to learn is that it is not only pleasant but desirable to contribute something to your school in the way of service, and we also feel that this invokes the civic spirit in them, that will live on after they are through school.

The first step in doing this is getting them acquainted with something that means service, that is our student council. It is the student council members that train our new students, teach them the rules and regulations and get them acquainted with the student leaders in the school.

For six weeks the students have various programs. The other day we had a Professor Quiz Contest, all of the questions in the Quiz were based on the school rules and regulations, the leaders, and various things they should know about the school. They have lesson sheets from which they study, and by the sixth week of school they are tested on all this information. This is called our Citizenship Test. All of the students who pass the citizenship test are permitted to participate in the extra-curriculum activities and really be considered a part of our school. We have our citizenship day program. At this time we recognize our service workers and accept the new students. This ties up the idea that a good citizen and being of service to your school just go hand-in-hand.

We have a very simple but impressive program. The new students take the pledge of loyalty, which is administered by our student city man- 
ager, at the same time they receive their certificate of citizenship which is signed by our Director of Service and our student manager. That day we also acknowledge our service workers by giving them these emblems. Each year we have a different type of emblem. This [displays emblem] is what we will have for our citizens in John Hay. The students like to wear something to show they are part of the school. Most of the information that students get for the test comes from our student handbook, in addition to the lesson sheets that are prepared by the directors of service of the student council, and usually every student passes the test, but it is not so much passing the test by itself, but it is really the spirit that we get by attempting to put over this citizenship program, and the students really do feel that when they know their school they really want to be a part of it, and in that way we have worked up our service organization so that the students feel no matter how little they do they are doing something. At present we have between fifteen hundred and sixteen hundrd students working actively in service for the school.

Dr. FRETWELL: When I ask all these people if they were you (imagining they were principals), and ladies and gentlemen of the panel, most of these people are principals, as you see by their grave and reverend looks -I am going to ask all of you folks here, if you were principals of high schools would you have a council? If so, why, and if you would not have a council, why not?

EDGAR BeCKER: If I were principal of a high school, I would be glad to have a council because it takes some of the work and responsibility away from a principal that he has to compete with, such as keeping the students out of mischief, such as giving them service to do.

Dr. FretwelL: My guess is that he is all wrong; I think if you have a council you have more trouble and more work than if you make all the decisions yourself. I don't believe you will get out of responsibility that way.

Mildred Guilfoyle: I think that a student council would be valuable for students, if it only did one thing, that is give them a sense of responsibility, which all real students get when they are graduating from school after student council service.

JoE Boydos: I agree with Edgar again, that a student council is necessary to the school to promote some of the school projects, such as tickets, and the citizenship activities, honor study halls, et cetera, which the principal might not be able to do all by himself, therefore I think the student council is absolutely necessary.

RoY UNGER: Certainly a student council is necessary, as was pointed out by Mildred, it develops a feeling of responsibility in the students in the 
activities they do. I can truthfully say many things in our school were started by students who had original and new ideas, and worked them out on their own initiative. The student council in our school does a great deal of good; I am sure it is the same in every school.

Russol Myers: I think student councils are fine because a principal would certainly appreciate getting the views of the pupils whose job is to direct. The students have funny ideas for some things, but they have fine ideas on others. I think as a principal he would get a lot of good ideas that would be profitable.

Evelyn LaWry: I too believe that student council is very necessary to school work, besides attempting to solve civic and social problems of the school and giving the student body a sense of responsibility it also reflects the student opinion to the principal.

Richard Little: I think student council is very necessary because it represents the ideas of the student body which the principal might not see without the council.

RAY Dotrore: I believe the student council is very necessary; we do a lot of business in our office, and so we relieve the principal of a lot of duties. [Laughter]

Lors Hainzezy: If I were a principal first of all I would have a council definitely, and second of all I would recognize the need to have a son or a daughter, because through that son or daughter I would feel that my reasoning would be better, I would go home, and say, "Son, what do you think?" because he has young ideas, and young ideas are necessary to a principal. [Laughter and applause]

Tim Gunn: Talking about young ideas, I might say that at Lakewood we have something different. During one of our home-room programs-

Dr. Fretwell (Interrupting): Don't make a speech, Tim; what do you think about student council?

TIM GunN: I was not going to make a speech, I was going to bring out something in connection with young ideas.

I believe student council is a great aid: It does prepare you for life. We all have to go into life, and vote, and take care of our civic problems, and our student council is a great aid to us in that preparation.

Nina Panarisi: I agree with all the other students that the student council is a necessity in a school, if you can have it. It not only develops responsibility, as Mildred said, but it develops a feeling of confidence, poise and a feeling of cooperation which you would not get in any other way. 
$\mathrm{R}_{\mathrm{AY}}$ Willson: As Mr. Johnston said, the school is composed of both the faculty and the students; there must be a coöperation between these two important groups, and that coöperation is achieved mainly by the student council. A council is a necessary part of every school.

Dr. FRETwell: Now we are leaving that particular topic and we have used up thirty-four minutes, if I count correctly. We will use about twelve or fifteen more, then we will throw the meeting open to you, and we will talk until about three minutes of four, and I will use three minutes to sum up, so you know the road from here on.

Ray comes from East Technical High School. We won't talk so much about publications, not that they are not so important, but we have got to economize time, so you do a little better job, Ray, than if anybody else was going to get in; cover your subject in about two or three minutes.

RAY Willson: Well in most high schools the object of the school paper is to acquaint the students, the faculty, and their parents, with the news of the school. The school publication is the voice of the school, it is the official organ.

At East Tech. we have a plan which is unique in the city at least, of instead of having subscription campaigns for every student, we have each home room subscribe as units.

In this way every pupil in the school gets our school newspaper. This is accomplished by having home rooms with an enrollment of say twentyeight or thirty-two pay a certain rate every week; home rooms with a higher enrollment will pay a proportionally larger amount. The school attempts a coverage of clubs, home rooms, honor societies, the office, and other organizations throughout the school to keep the students acquainted with what is going on.

Our student paper has about thirty-five hundred persons subscribing to it. This includes all our students, the faculty and some alumni, and most of the students take their paper home to their parents, and I think that this is perhaps one of the most important things which can be accomplished in any school--to have the parents learn what is going on.

The school is a factor in the community to better it. If the parents are interested in the school through the school newspaper, they can learn of what is going on, and in that way help to better any community.

Besides school newspapers there are various other publications. Almost every school has a handbook, usually published by the student council. This handbook, at least ours is, is distributed to the meetings, it tells of our clubs, of our council work, newspaper work, school courses. It contains a brief review of the school history and other things of a like nature. 
Besides that, there may be a literary publication of some type published throughout the school year. This may consist of prize winning stories in English classes; in our school we have no junior annual, but I know of several high schools represented here that have. Of course the main annual is the senior edition.

Our annual is published in both February and June; it costs one dollar for every graduating senior; there are about five hundred members of the junior graduating class and at the present time we are working on, we have started work on, our annual. This is the thirtieth year that East Tech. has done work in technical training, and the annual staff has decided to dedicate the junior book to the ideals of technical education.

Dr. Fretwels: Will you bring out the idea as to whether you have journalism classes or not, which in any way prepare for these publications or are they solely made up of interested teachers and pupils outside of curriculum?

RAY WILlson: Our school newspaper is composed of about thirty to thirty-five members, student members, and five faculty advisors. We have two for the editorial staff, one for the business staff, and two for the printing end of it.

Our paper is published in our school. All pupils who wish to get on the staff are required to take a semester of theory training. They get no actual work for the student newspaper until their second semester when they become cub members. Students are allowed five points a semester for this, a maximum of four semesters credit.

On the other publications there are no requirements in the preparation. We have tried to pass around the posts, as Mr. Johnston has said, by not having the editor of the school paper become the editor of the annual, as is true in many schools I know of, and so we make the editor of the student paper ineligible for major positions on the annual staff.

The annual is usually composed of interested persons, in that type of work. The student council handbook is usually put out by a committee of the president of the council, the editor of the Scarab, and various other board members with the help of our student council advisor in that.

Dr. Fretwell: Thank you, Ray. I am particularly interested in that myself because of the fact that Cleveland and this part of the country has long been known for its achievements in getting the newspaper work rooted in the curriculum. It is one of the things done in earlier days here, and we are still comparing people like Miss Margaret Sullivan, and Claire Ewald, with Edith Penny, pioneers in this field of developing school newspapers that were rooted in the curricular work of the school, and still had the extra-curriculum flavor too. I remember when Miss Claire Ewald and 
Margaret Sullivan got jobs on the Plain Dealer at twenty dollars a week, and learned a slice of life that these ladies would otherwise doubtless not have learned at all.

RoY UNGER: May I interrupt a moment? I would like to add that at our school we have a novel feature. Latin may be a dead language, but at our school we have a Latin newspaper published four times a year by students chosen out of the advanced Latin classes, a four-page edition with four columns in it. They get a lot of fun out of printing, publishing it and the students of Latin in their classes have a lot of fun in translating it. They have certain articles in Latin, some in English, and there are a lot of jokes and crossword puzzles, et cetera, and it has proved very interesting at our school.

Dr. FRETwell: I heard a definition of an optimist-a man who works his crossword puzzles in ink. [Laughter]

How many of you people here come from schools that have school newspapers?

... all raised hands. . . .

Just look!

How many of your schools have handbooks?

... two or three hands raised. ...

Thank you very much; now we want to travel along.

You know this party would not be complete, for Harry Church at least, if we did not get an idea of whether we have any Honor Societies represented in Cleveland-is that right, Mr. Church? I wouldn't disappoint an ambitious young man like Harry Church.

Mr. Church: Thank you, thank you, thank you.

DR. FRETweLL: You may delete that from tine record. [Laughter]

How many of you senior high-school people come from schools that have chapters of the National Honor Societies?

... seven raised hands. ...

How many have some other type of honor society, any of you?

... one. ...

Lois, will you take the "mike" and tell us a bit about honor societies as you see it, regardless of what anybody else says?

Lois Hainley: Well at West High School the Honor Society was organized in 1930. It was about 1970th on the list. This was all new and interesting to me, to find out, because until a wcek ago I did not know some of these vital statistics. Naturally the requirements carry good leadership, scholarship, and service, and are the same as almost anywhere you find a National Honor Society chapter. 
The constitution complies with the national constitution but there is a difference in method of election. This was news to me, too. I really had not thought about it much. Our method of election at West High School comes in about three stages. We have first a questionnaire circulated to all people who are anywhere near eligible for the Honor Society; secondly, after these questionnaires have been turned in, I might say the questionnaires cover every phase of the student's life possible; there is a place for home-room offices, and all clubs that we belong to, all musical organizations you belong to, dramatic organizations, your average thus far in school-everything about you.

Second in this method of election is the general faculty meeting which is held; students are then suggested whom the faculty believe worthy to be members of the National Honor Society; then as a third and final step, when these students have been looked over, and according to their questionnaires it has been decided whether or not they are eligible, there is a final decision made by an Honor Society committee. I don't know, but I imagine this committee is made up of different faculty members each year; I cannot say for sure, and the upper third-or it has been customary that the upper third-of the class is eligible; five per cent of the 11-A's, five per cent of the 12-A's, and five per cent of the 12-B's fifteen per cent in all, eligible to come into the society. This is a maximum, but not a minimum, for many times they do not take in the full number because perhaps they do not feel the others are worthy of this honor.

I was rather shocked when I heard that the Honor Society members were taken in first by questionnaires, then by general faculty meeting, then finally by an Honor Society committee not made up of any students of the National Honor Society but of faculty. Many students in the school are inclined to believe that many worthy Honor Society students are eliminated. We have to expect that because it is a limited society, but many feel that the Honor Society member of to-day is the stuffed shirt of to-morrow, because he is a teacher's pet. That is not the case at all. There have been Honor Society members undoubtedly who have gone so far ahead in scholarship that they have left service way behind somewhere, where they kicked it aside because they were so interested in their studies. This is no reflection particularly on the student, he is merely very scholarly and interested in what he is doing, but as I see it, I feel that in any school the National Honor Society membership should be elective, with suggestions by faculty members; yes, they are in position to know the student definitely, but the Honor Society members should have something to say about this; the Honor Society student member of to-day is not the stuffed shirt of to-morrow; we have a lot of live, human people in our Honor Societies to-day, but they can be a lot more alive and a lot more human if faculty members recognize the great need that we have to look through the stu- 
dent's viewpoint, and as Dr. Johnston said, have faith in him, because that is what we need-faith-so that you know that we may have an idea that just by chance nay be worth something.

Now, there is one more thing I wanted to say: we have never expelled anyone at West High, but three unexcused absences should automatically expel one from the club, and of course failure to live up to the ideals of the club. I don't think that has ever happened.

About two months ago, I believe, I attended a city-wide meet where there was a representative from each school, of their National Honor Society; it was agreed at that meeting to have two meetings per semester, one a social and one a business meeting. We agreed to hold the place of meeting alphabetically. I remember we went to Collinwood.

So far as: what does National Honor Society at West High do for West High? Well in any case where they need good dependable people, people they know they can count on, for instance, in guiding, ushering, or helping out as at this convention which is here in town this week (I know of Honor Society members who are helping out down here); we also tutor. We have not gone far with the tutoring this year, but as the occasion arises we will tutor students who are having trouble, in our free periods. We have eight honor study halls. We generally put two Honor Society members in these honor study halls and I imagine we have approximately two hundred and forty students enrolled in them. I might say that last year the honor study halls were not successful. I am saying this because you can improve them. This year our honor studies are much better than they were last year. Students somehow recognize their responsibility and find it just as easy to be quiet as to shoot paper airplanes around the room and make a lot of noise, and believe me they do it in honor studies at times. This year we have had such a vast improvement that that kind of thing doesn't exist any more.

Dr. Fretwell: What seems to be the trouble? Why were they bad a year ago compared to now?

Lois HaInley: That is something I can hardly answer. I was so surprised this year when I enrolled in honor studies and found them so different from last year. I can't answer it. I think they are used to it. You put something new into a school and maybe the first year it is unsuccessful but suddenly they become accustomed to it and for no reason they take it for granted and settle down.

Dr. Fretwell: Would you advise the principals if they try out something and get a little discouraged, to keep on hoping?

Lois Hainley: Definitely. I think we can say that more at West High than they can in a lot of places. We have tried a lot of new ideas in the 
past three years and I started in at West High when the student council started at West High. We are a very young student council; we have accomplishsd a lot. I would say: don't give up, say you will always improve; there is always room for improvement, and there will be improvement. [Applause]

\section{Dr. Fretwell: Thank you.}

One other main topic I want to take up. We have not covered in this at all the relations of the school and the community.

A lot of these people are sending me notes saying that we are skipping some of these things. I want to take up one particular idea, and ask Miss Lawry to talk about that, to bring out the relation of these student activities to the community. I want her to bear down on that.

Evelyn Lawry: Through the work of the children in school, the people in the community will be more interested and they will help the school out a lot.

I know in Garfield, the community helps by subscribing to the newspaper and also by placing ads in the paper, which add to our financial part of the paper.

But possibly the greatest coöperation that we have ever had was during the last two months of the campaign of last year, August and September. It was during those two months that we passed the bond issue. In the August primary voting we put up the bond, which had to receive a sixty-five per cent majority; however on the first vote it only received a fifty-eight per cent, and of course we were greatly discouraged when we came back to school, we had three weeks to work on the bond issue to make it pass. This bond issue would give us larger school, an auditorium from which we could graduate, and we would not have to go to another school, it would give us more rooms, and we would have better study periods, and also we would have longer study periods. On this bond issue we went out and we really made the people vote for it. At the first voting we were more or less a handful of people, however, during the second vote we had seventy-five per cent of the people of Garfield Heights out to vote. In other words we had not just a handful of people who were for it, we had seventy-five per cent of the whole community. We had this bond issue passed by an almost eighty per cent vote. Due to this we can have our larger school which is to begin next year.

We had girls go out and where voters could not leave their small children, they would stay in the home and take care of the children. [Applause] We also had cars go out and pick up people who would not vote because they had too far to walk. We had one of our faculty advisors in charge of this, and he arranged it so that these people would be 
picked up, taken to the polls and taken back and in that way they votedwhether they voted yes or no.

It was also during that day that we had girls and boys stationed outside of the booths, who handed out literature concerning the bond issue. Many people thought if it was passed they would have more taxes to pay and didn't want to vote for it for that reason, but we told them that this wasn't so. We had many parades, and we had it all worked out, and we could prove that the taxes would not increase, but that they would more or less decrease. [Laughter]

We also had parades, as I said, and we would take some of the popular songs, for instance, "Stop Beating 'Round the Mulberry Bush," which we parodied to, "Stop Beating 'Round the Bond Issue."

We had different items of publicity, and the people thought: we may as well vote for it, and get it over with, and give them their larger school. [Applause and laughter]

As a result it was passed by an eighty per cent majority and our school enlargement is now in process and you will see next year that our work was well repaid. [Applause]

Dr. Fretwell: By my watch it is now three minutes to four; would you like to ask questions? If you would, would you like to stay here if I will promise to let you out at four-fifteen? We are willing to dismiss you whenever you want; we don't want anybody walking out. How many would like to devote fifteen minutes to questions from the floor and dismiss at four-fifteen?

... from a show of hands the large majority desired to remain. . .

We haven't covered as many things as we would like to do, as you can readily see.

If you want tc stay fifteen minutes more we will be glad to have you stay, if you want to go, we will be glad to have you go now rather than during the fifteen minutes. It is a perfectly honorable procedure to go now, if you want to. I always like to finish things with real distinction, and we believe in freedom.

A few seats down in the front have been vacated, if those of you in the back want to come down please come down. I happen to be a Southern Baptist and we usually extend the right hand of fellowship to those who come down in front but we will pass that up for today. [Laughter]

I think we will work it out faster if you will write your questions on a piece of paper. Dr. Williams, will you go down and collect the questions?

Now while you are doing that we will go on. 
I have a million questions I want to ask, myself.

One of the first questions which was asked is:

What is the main quality that you like in a sponsor of any activity, home-room or club or council, or whatever it is? Not all the qualitiesyou need not describe the perfect person, but one or two things you particularly like. Is that a fair question?

Question from the Audience: What do you mean by sponsor?

Dr. Fretwell: I mean the adult person, the teacher who acts as sponsor.

RAY DotToRE: If your sponsor has faith in you, that I think is the main thing.

LoIs Hainley: I think one of the things that a student likes in a sponsor, not particularly a liberal one, not that at all, but a definite interest and a broad-minded attitude that is able to see our viewpoint.

Tim Gunn: We always like to have a good spirit of coopperation and if we think a plan can work, we like to have the faculty sponsor behind us, and not leery of the whole program.

Nina Panarirsi: We like to have one who takes a natural interest in the students and in the projects which they are sponsoring. I think that is one of the most important factors in being a sponsor for anything.

RAY Willson: I think the students of to-day want not a faculty sponsor but more a faculty advisor who advises the students as to what they can do. Some sponsors may take a leading part in council affairs and they should, but I believe that in the council or in any other organization for that matter, the main pushing of any idea should be by the students and that the faculty sponsor should advise them with his or her wcaith of wisdom gained in the time they have been teaching.

Evelyn Lawry: Besides having an advisor who is coöperative and who really takes an interest in it, I also think the advisor should also make suggestions that she thinks will be worth while to the school but which have not been made by the students themselves.

Russor Myers: I feel that most advisors are usually pleased to see that the meetings go along all right, so I think that most advisors, in fact all advisors should be able to understand and appreciate the troubles that students might run up against.

Dr. Fretwell: You get the tune of the thing-if you don't mind we will go on. Here is the next question:

Would you suggest that the sponsors stay away from meetings, acting as advisors from a distance? 
Edgar Becker: I would like to say that I don't see how a person can act as an advisor if he doesn't know what is going on in the meetings? He would have to be present at the meetings in order to act in an advisory capacity.

Tim Gunn: I believe that when the student council advisor is not there students feel more free to get up and say what they feel, but if they figure the assistant principal or somebody is going to check up on them, they are not as free.

Mildred Guilfoyle: I disagree. I think especially in a large school where you have a large student council it is sometimes the only opportunity the advisor has to speak to the entire council as a body, and they should be at the meetings and should work right with the council at all times.

Lors Hainley: What Tim just said, that the students would feel more free to get up and speak if the advisor were not present suggests the answer and that is: don't be that kind of an advisor, be the kind of an advisor with whom the students could feel free to say what they want to say. [Applause]

Dr. Fretwell: This particular question is yours, Tim, I think:

How are activities planned?

Tim Guns: Well at Lakewood we try to back our activities through an activities pass. This project originated in the student council; it came in five years ago. I know there are a lot of schools that would like to have activities passes. You must keep one thing in mind: get the students behind them, not just the teachers.

At Lakewood they tried something before, and it had failed; then the student council decided to back this plan and it immediately went over.

We started with the football pass, which just included a ticket that sold for one dollar, to eight games. This proved so successful that the following year we went ahead and decided to have a regular activities pass, and on this activities pass we gave seven football games; seven basketball games, seven baseball games, four tennis meets, four track meets, four swimming meets, and four wrestling meets-thirty-seven events in all, which if you had paid separately would have totaled seven dollars and fifty cents, but if the student bought a pass cost him two dollars. If a student is a good business man, he knows that is quite a saving--five dollars and fifty cents-you can buy a lot of sodas, with that.

Joe Boydos: At John Adams we have a more simple activities thing, it is composed of only three football games, the journal, and the movie pass. The movie pass is two cents a day at our school, and there are ninety 
days to the semester which is a dollar and eighty cents, and our Journal, that is twenty cents per semester-that is two dollars.

However, we have found out that we could not go into a detailed activities ticket because of the insecurity of the sales, so we started out by simply having a football pass, graduating upward. At the present time we do not believe in enlarging our football pass or any other part of our activities ticket because we have done fairly well. Last year we sold in the neighborhood of two hundred activities tickets at a dollar and a half, and this has gone into a general fund and has supported all our athletic activities.

At the inter-school forum in discussing activities tickets, Miss Parmenter, our advisor has commented on the fact that we should not start out with a detailed activities ticket because there is liable to be a failure due to insufficient backing.

A lot of other schools have very detailed activities tickets, such as Tim has at Lakewood. This fellow from South also has quite a detailed activities ticket. However they must start with the minimum activities ticket if they wish success, and the student council must get behind everything in an effort to drive and succeed for the various activities through the activities ticket.

Dr. Fretwell: One more on that.

Miss Guilfoyle, Mr. Moore at your school told me one time if I remember correctly they sold activities tickets that had many activities.

Mildred Guilfoyle: That was before my time at John Hay, but it was said that you cannot have a lot of activities on an activities ticket, and have it succeed. I disagree. We brought our activities in two semesters ago, I think we could call it absolutely successful; over one whole school year it would be three dollars if you paid it on time payments, it was two dollars and fifty cents for a cash payment and in that ticket we include football, basketball, wrestling, the Ledger, the paper . . . our Humors, a book made up by the English classes of essays, poetry, short stories, the Art work, done in our art classes, the Jamboree, which is a grand show we have during the Spring semester, a concert, and a Varsity-Faculty basketball game, which we all like so well. We take that in on our activities ticket; it has been quite successful and we have all the activities on it, and we have found that it is much better than trying to have separate athletics passes as at Lakewood-it just seems to be athletic activities there, but we take in everything on ours, and if they wish to buy it for one semester it is one dollar and a half.

DR. FRETwell: Here is another question to the panel:

Would you like for someone to use the power of the veto such as the 
principal or the superintendent? What do you think of the veto idea on the part of the principal or the sperintendent?

Edgar Becker: For one thing, sometimes legislation is passed which the student may deem absolutely necessary and for some reason or other it may have succeeded in other schools, but the principal may feel it would not be successful in our school. I feel in some cases the student should be given a point to prove, the point before the principal or advisor vetoes this. We cannot do anything if we have not a chance to show our metal.

Russol Myers: In the lunch room at our school there is a very crowded condition; also we find that quite a few of the students would enjoy having the privilege of ... We brought this up in the student council and executive meetings and talked to the principal and he vetoed it. He did not even give us a chance to prove that we might make a go of it, because of the fact that six years ago or so they had something there of the same type and they did not make a go of it. I told the principal that we would appreciate it if we could try it; he seems to think we could not make a go of it. I wish for that fact, that they didn't have such a great power of veto so we could try it.

Dr. Fretwell: Here is a question:

Does the student council meet on school time?

Evelyn Lawry: We meet at two-thirty every other Tuesday.

Dr. FRETweLL: Is that the end of the school day?

Evelyn Lawry: No, Dr. Fretwell, it is not; it is regular school time.

Joz Boydos: Our student council is elected by the home room; we guaranteed nine periods off for student council meetings every other Tuesday of the month.

Mildred Guilfoyle: We have it the same way. We have our tenth hour regular class period-every council member has tenth hour free.

EDGAR Becker: Our student council meetings rotate from one period to the next.

DR. FRETwelL: How do you get in the honor study hall?

Lors Hainley: The system used in our school-I noticed one of the other schools is a little different-the home-room teacher announces in the home room, there will be for such-and-such a period room such-and-such for honor study hall; if you would like to sign up for that-and students who wish to sign up for the honor study hall with the approval of the home-room teacher are placed in there. 
Dr. Fretwell: I hope all of you have read the articles by Ethel Parmenter on the Honor Study Hall; if you have not-it is assigned.

How large are your home rooms in senior high school?

RAY WILLson: Our home rooms consist of about thirty-five members; we have about a hundred home rooms, and thirty-five hundred pupils in our school.

Nina Panarisi: At Collinwood we have about forty to forty-seven in a home room, that is about the average.

Tim Guns: Our home rooms consist of about forty and in the 12-A year all the seniors are thrown together and we have home rooms of two hundred and fifty.

Lors HAINLEY: We have about an average of forty members in a home room at West High.

Dr. FrETwell: Here is a question-I am reading them just as they come:

Ask these young people whether or not they feel the Honor Societies are truly democratic organizations and worthy of inclusion among our high-school organizations.

Does anybody want that?

RaY WILlson: Most of them, emphatically, the National Honor Society should be a vital part of your school work; at our school we have two Honor Societies, one the National Honor Society where students are elected or selected by the faculty committees, and our other honorary society the members are chosen by the students themselves, and we find that about ninety-nine times out of a hundred the same boys get into both honor societies, although the students are generally more strict than the teachers are in judging.

Roy UnGER: I believe the Honor Society is a good thing, when the school makes it a good thing. I think our school has made Honor Society a good thing. At Heights the teachers are the only ones who select candidates; they go through this process very thoroughly and carefully, and try to get the student they really feel deserves membership in the society. The society isn't a dormant and stagnant one, and a person just gets in, but it is a live wire organization active at all times. The members in the Honor Society at Heights perform services for teachers in the form of tutoring and as secretaries. We are required to have fifteen periods of service every semester if a person doesn't get these fifteen periods he is not kicked out of the organization, he is asked as a matter of honor to get them, and we find that all of the members of the Society live up to this requirement. 
This year we have tried something new, that has proved successful, that is an anti-cheating campaign; that is a pretty ticklish subject, but in past years there has been a lot of criticism, members of the Society have inclined to cheating, we have drawn up a code of what we call cheating and not cheating; we have discussed it thoroughly in the Society, and by these discussions all the members of the Society have raised their individual standards and we are pretty clean and dry at the present.

Dr. FRETwell: A very funny thing has happened here. You see that question came in: are they democratic organizations? You may have noticed that our young people are not interested in playing with words in the abstract, or with abstract ideas; they very definitely got at what was the thing. They are not scared about this word democratic, whether it is or isn't, that is left for the calamity howlers mainly; these people are working. [Applause]

Is there any limit as to participation?

That means are they limited in the number of activities one student can go into?

May we hear these young people discuss this?

Evelyn Lawry: If a student participates in more than two extracurriculum activities he does not keep up well in his work, we have found. By participating in two extra-curriculum activities or clubs he can do more and better work in those two than if he participated in five and did not devote enough time to each.

LoIs HaINLEY: We have considered recently limiting extra-curriculum activities. I can frankly say from my own experience that when you try to do too much you do not do any of it well and it is hard on your health, your mental and physical activities both. I have tried it. I wouldn't give up my four years for anything, but $I$ have been so busy that leisurc is a word I hardly know the meaning of.

DR. Fretwell: We have a wonderful notion that youth has leisure. Here is this question:

How many schools represented have courses in Journalism?

. . . all of them raised their hands but one . . .

You will notice the junior highs are up too.

How many of you publish an annual?

... five hands went up ...

Thank you.

There was one time when all schools had annuals, they went over into getting out a special edition of the newspaper; it seems to have slipped a little since then, but it seems to be about fifty-fifty on that question. 
A MEMBER FROM tHE FLOOR: I would like to have the answer of these young folks to a suggestion Dr. Johnston made. He thought maybe only certain folks should be allowed to take action in extra-curriculum activities.

Dr. FRETwell: The question is whether there should be qualification in respect to grades in order to be able to participate in extra-curricular activities?

Nina Panarissi: I think there should be some limitation as to what your grades are supposed to be. After all, as the girl from West High said, if you have too many activities that take up your time you don't do anything well. Well, if you have too many activities that take up your time how can you give any attention toward your subjects? You have to have a pretty good average to keep up the extra work.

Lors HaInLEY: I want to say one thing in answer to that: I meant that belonging to too many extra-curriculum activities rather than this grade limitation-I say this: that many students go through high school lost because they have one thing they are interested in and do not know what it is. Through an extra-curriculum activity this student might find something where his energy can be devoted, and because of that will be a finer person. We should not limit people in extra-curriculum activities with grades of eighty-five or above. I do not approve of that at all. Some people have gone through high school whose averages have been seventy and above who have been our leaders of to-day, right now in Cleveland, or in New York City or in all the big cities.

I say eight-five or below is all right; some people don't get the grades but they have a certain energy and ability that they can devote to one particular thing.

Mildred Guilfoyle: I think particularly we are in school for an education and after all if we cannot get the best of our education, things that are offered to us, we cannot do the very best for our school, and although everyone becomes a student leader does not have to be an honor student at the same time he should attain a fairly good average because average intelligence is needed to handle the sort of jobs that the student leaders are taking on in high school to-day.

Dr. Fretwell: I don't know whether we are going to cover all the questions or not. I shall take one more:

Do you prefer planned home-room programs other than entertainment for the longer home-room period? Do you like home-room programs planned or what do you want?

Richard Little: Well in Empire at the beginning of the semester there is a bulletin that comes out and it gives the programs that we are 
supposed to have the different weeks and every other week we are supposed to have a program, it says what it is to be during this time and the home-room committee that has been appointed goes and gets reference material and looks it up and then on a certain day gives the program, and we find that this is very successful in Empire, because it takes up most of the interesting things, and also it brings out entertainment once in a while.

RUssol MYers: I think planned programs are good but sometimes your plans go wrong in school, so you cannot have it too definite. We usually find our programs go over very big and that is what counts in the home-room period.

Edgar Becker: I should say that a planned program in advance would be the best thing, such as teaching pupils how to study, would be a main home-room project during the semester which would be heneficial both for the student and for the teacher.

Dr. Fretwell: To live up to our end of the agreement, in respect to time I will make it very brief on the summary.

There are one or two things briefly that I want to say. First, as I see it from the young people's point of view, and the adults' point of view, we are trying through this means as through other means of the school to provide an opportunity for educative experiences on the part of these people who are learning. I think it has come out in this afternoon's session that guidance and supervision and teaching are just as necessary in learning these arts of citizenship as is teaching in algebra or in Latin or something else.

Probably we recognize that teaching and guidance in these learning fields that the young people are talking about namely how to be responsible, how to assume responsibility, how to lead, how to get along with other people, that teaching in those fields, guidance in those fields is harder probably than any other kind of guidance, and teaching in the world.

I call on all parents to back me up on that point, because that is what we are trying to do in the family home room.

Again, it is perfectly plain to me as has come out from our discussion here that we are desirous of running well organized, well ordered, efficient schools. It seems to me that there are just two dominant ideas in the mind of folks like you adults and myself, and I think our young friends here: in this field in two things-one through the extra-curriculum activities, which is only a part of the school work in the direction of a wellordered widely participated in society, that is in an efficient school; on the other hand to give people an opportunity to contribute to the school-all of them-to have not only to contribute, but to have the will to contri- 
bute, and not only the will, but the developing of ability to contribute, and I think that is what this thing is all about.

These people of increasingly good-will, share in making decisions up to the level of their ability or a little beyond, maybe, and it is in this field that we are so concerned, and I thank all of you in this group, Miss Parmenter, thank you very much, and I thank the principals behind you.

If I were the Old Lady who Lived in the Shoe, if I had all you children I wouldn't have too many, I would just like a gang like you to live with [applause] and I think I might tell the ladies and gentlemen of the panel that to those at least of my age and experience-and this is my quarter century in attending these meetings-that this has been to me one of the most delightful and refreshing experiences that I have had in any of these meetings here, and I think, by the way, the ideas flew about as rapidly this afternoon as at any time in the meetings, especially in those meetings where I read a paper.

Thank you all very much.

... the session adjourned at four-twenty p. m. o'clock. . . . 